\title{
Dialectics of Dairy Farming Enterprises and Dairy Farmer Community in Pangalengan West Java
}

\author{
Muhammad Ali Mauludin*, Viani Puspita Sari \\ ${ }^{1}$ Universitas Padjajaran, J1. Raya Bandung Sumedang KM. 21, Hegarmanah, Jatinangor, Kabupaten Sumedang, Jawa \\ Barat 45363
}

\begin{abstract}
Dairy farming business in Pangalengan has been established since Dutch colonial goverment set in and it continues until today. The business encountered such dynamics, in which aligned with political changes took place in Indonesia. Situated in Southern West Java, Pangalengan has been an icon of dairy farming in that it is major occupation of Pangalengan inhabitants. Capital owners were atracted to invest there, make capitalism penetration occured during some periods and developed quite well. Koperasi Peternak Bandung Selatan / Dairy Farmer Cooperative of South Bandung (KPBS) which is famous for its pro-community development then emerged and established along with the massive development of dairy farming in that town which later gave big contribution to development process. One of them is the establishment of a new private dairy farming plant in Pangalengan. Dillematic situation then occured. There were pro and contra against the existence of that private enterprise amongst the Pangalengan citizens. One group thought that the enterprise would generate the development process in Pangalengan, while others considered that it would create a clash with the community dairy farmers who have existed long before the independence of Republic of Indonesia. This paper will discuss dialectics of Private Dairy Farming Enterprise and dairy farmers community in Pangalengan. Both perspectives of private dairy farming enterprise and dairy farmers community will be the study in this paper. Positive and negative aspects are constructed in the arena or dialectics of dairy farming development.
\end{abstract}

Keywords: Dialectics, Enterprise, Community, Dairy Farmers

\section{Introduction}

According to Marx as cited by Peet and Hartwick [1], dialectics is a theory of development that sees all things as complex wholes composed of parts. The inner relations binding the parts of a thing together have to be complementary and cooperative so that an object has coherence - for example, the mind is in touch with the body within the whole person, or commodities have cooperative social relations among one another within the total society. Yet inner relations are also contradictory, giving an object immanent potential for change - for example, body and mind can move in different directions (the body constantly contradicting the mind's intent), or communities can be riven with conflict, as when one class or gender exploits another.

There is also an "outer" external dimension to dialectical thinking that is especially appealing to theorists fascinated by earth space. In the "spatial" dialectics, an object also develops through "inter" relations with the external environment of other things, and these relations are likewise simultaneously both cooperative (trade, when it actually benefits all partners) and competitive (one society extracting value, resources, and people from another)[2].

Furthermore, fundamental transformative change occurs when contradictions build to the breaking point - for example, when two people can no longer stand the sight of each other and their relationship disintegrates; or when environments are destroyed by overproduction and too much consumption, the climate changes, and society is transformed by catastrophe; or when one class super exploits another to the point that the exploited cannot not have transformative effects unless an entity, held precariously together by contradictory internal relations, has already been made highly unstable by inner contradiction and conflict. The developmental process is thus a synthesis between inner and outer dialectics; the two aspects of change (inner and outer) alternate in significance; the types of their interaction are multiple and complex [2].

\footnotetext{
${ }^{*}$ Corresponding author email mali.mauludin@gmail.com
} 
In line with development discourse, particularly development of dairy farming subsector, Indonesia was faced with multifaceted problem - on one hand, Indonesia needs to keep up with food security, but on the other hand needs to maintain dairy farming. Moreover, in 2004, under the precidency of Susilo Bambang Yudhoyono launched Self-Sufficient of Beef and Carabeef Policy in order to achieve fulfilment of meat demand from the citizens. The policy then stimulated decrease in dairy cow population as the dairy farmer tempted to sell their dairy cows to "calo/pengumpul/belantik/bandar" (acted as broker) instead of rearing them. This occured because the price of meat at that time was expensive, ranging from Rp.100.000,- up to Rp. 120.000,-/kg [3]. Not surprisingly, there was decrease of dairy farmer ever since. In 2012, there were 5031 farmers, and nowadays the remaining number of dairy farmer are 4690 farmers [4].

The objective of this paper is to analyze the condition of dairy farmer community in Pangalengan, Bandung Regency, West Java Province that incorporated as active members in KPBS amidst the emergence of dairy farming enterprise who possesses greater capital, wide range of access and latest technological know-how.

\section{Methodology}

The research was conducted in Pangalengan Sub District, Bandung Regency, West Java Province which is part of working field of Dairy Farmer Cooperative of West Bandung (KPBS). KPBS has three working fields in three districts that are in Pangalengan, Kertasari and Pacet. From those three districts, Pangalengan has the biggest population of dairy cows. The choice of location was made based on historical background and it was assigned as center of dairy farming in West Java.

The research was conducted by using qualitative method. Data and information were gathered through direct observation, in-depth interview with the informers, and complemented by library research on documentation. Validity test was conducted through triangulation technique.

\section{Discussion}

The Indonesian dairy industry is based on smallholder farms grouped into cooperatives. Farm size is small, with most farms having no more than three to four head of milking cows. The dairy farms are based on confined rearing of cattle with forage grasses being gathered from outside the farm in a "cut and carry" system. This involves the farmer or agricultural laborers (some of whom may be farmers), cutting and collecting grasses from the farmer's land, or from along the sides of roads, irrigation ditches, forests or other such places [5].

In the 2010-2017 period, there were around 4690 dairy farmers in Pangalengan, grouped into
KPBS. As has been collected from the direct observation and found from secondary data, here is the lists of the major problem facing by dairy farmers community presented in Table 1 :

Table 1: Major problem faced by dairy farmers community

\begin{tabular}{|c|c|c|}
\hline $\begin{array}{l}\text { CONSTR } \\
\text { AINTS }\end{array}$ & $\begin{array}{c}\text { SUBCLASS- } \\
\text { CLASSIFICATION }\end{array}$ & EXPLANATIONS \\
\hline Nutrition & $\begin{array}{l}\text { Availability of forage } \\
\text { grasses } \\
\text { Lack of water } \\
\text { Quality of } \\
\text { concentrates } \\
\text { Nutritional } \\
\text { management }\end{array}$ & $\begin{array}{l}\text { Only happened in } \\
\text { drought season } \\
\text { Idem } \\
\text { Idem } \\
\text { Idem }\end{array}$ \\
\hline $\begin{array}{l}\text { Herd } \\
\text { record } \\
\text { keeping }\end{array}$ & $\begin{array}{l}\text { Low level of herd } \\
\text { improvement } \\
\text { Non identificatiom of } \\
\text { animal health } \\
\text { problems }\end{array}$ & $\begin{array}{l}\text { Has been solved by } \\
\text { KPBS } \\
\text { Idem }\end{array}$ \\
\hline Hygiene & $\begin{array}{l}\text { Lack of water } \\
\text { Increase in mastitis } \\
\text { incidence } \\
\text { High level of milk } \\
\text { contamination }\end{array}$ & $\begin{array}{l}\text { Only happened in } \\
\text { drought season } \\
\text { Idem } \\
\text { Idem }\end{array}$ \\
\hline $\begin{array}{l}\text { Animal } \\
\text { Health }\end{array}$ & $\begin{array}{l}\text { Many deseases } \\
\text { Lack of resources for } \\
\text { veterinary staff } \\
\text { Lack of experience } \\
\text { and education }\end{array}$ & $\begin{array}{l}\text { Has been solved by } \\
\text { KPBS through } \\
\text { veterinarian and } \\
\text { mantri (veterinarian } \\
\text { assistant) } \\
\text { Idem }\end{array}$ \\
\hline Genetics & $\begin{array}{l}\text { Inapropriate genotype } \\
\text { for Indonesian } \\
\text { conditions } \\
\text { Long calving intervals }\end{array}$ & $\begin{array}{l}\text { Has been solved by } \\
\text { KPBS through } \\
\text { veterinarian and } \\
\text { mantri (veterinarian } \\
\text { assistant) } \\
\text { Idem }\end{array}$ \\
\hline $\begin{array}{l}\text { Extention } \\
\text { provision }\end{array}$ & $\begin{array}{l}\text { Lack of resources to } \\
\text { train/provide } \\
\text { extension workers }\end{array}$ & $\begin{array}{l}\text { Has been solved by } \\
\text { KPBS }\end{array}$ \\
\hline $\begin{array}{l}\text { Milk } \\
\text { processing }\end{array}$ & $\begin{array}{l}\text { Pour quality of milk } \\
\text { Lack of technology } \\
\text { applicable to the } \\
\text { village }\end{array}$ & $\begin{array}{l}\text { Mechanization by } \\
\text { the dairy farmers } \\
\text { who have already } \\
\text { had training given } \\
\text { by KPBS }\end{array}$ \\
\hline $\begin{array}{l}\text { Marketing } \\
\text { systems }\end{array}$ & $\begin{array}{l}\text { Highly variable price } \\
\text { Dependence on Milk } \\
\text { Processing Industry / } \\
\text { Industri Pengolahan } \\
\text { Susu (IPS) }\end{array}$ & $\begin{array}{l}\text { Depends on milk } \\
\text { quality } \\
\text { PT. Ultra Jaya } \\
58.50 \% \\
\text { PT Frisian Flag } \\
\text { Indonesia } 26.50 \% \\
\text { KPBS Processing } \\
\text { Unit } 11.10 \% \\
\text { PT. Indolakto } 2.00 \% \\
\text { Home Industry } \\
1.80 \% \\
\text { PT. Isam } 0.10 \%\end{array}$ \\
\hline
\end{tabular}


Meanwhile, the dairy farming enterprise that has been residing and has actively been operating in Pangalengan since 2010 possesses immense modes of production comparing to dairy farmer community as shown in Table 2 as follows:

Table 2: Comparation of production modes between dairy farmer community and dairy farming enterprise [6]

\begin{tabular}{|c|c|c|}
\hline \multirow{2}{*}{$\begin{array}{l}\text { Production } \\
\text { Forces }\end{array}$} & \multicolumn{2}{|c|}{ Modes of production } \\
\hline & $\begin{array}{l}\text { Dairy farmer } \\
\text { community }\end{array}$ & $\begin{array}{l}\text { Dairy farming } \\
\text { enterprise }\end{array}$ \\
\hline $\begin{array}{l}\text { Production } \\
\text { tools }\end{array}$ & $\begin{array}{l}\text { Land (stall, } \\
\text { forage) }<0.5 \mathrm{Ha} \\
\text { Population of } \\
\text { milking cows not } \\
\text { more than } 30 \\
\text { Conventional stall } \\
\text { Size of Milk Can } \\
10-151\end{array}$ & $\begin{array}{l}\text { Land (stall, forage ) } \\
>1 \mathrm{Ha} \\
\text { Population of } \\
\text { milking cows not } \\
\text { more than } 1000 \\
\text { International } \\
\text { Standard Stall } \\
\text { Warehouse for } \\
\text { concentrate } \\
\text { Mechanization of } \\
\text { Milking Process } \\
\text { Direct Milk Storage } \\
\text { to Cooling Unit }\end{array}$ \\
\hline $\begin{array}{l}\text { Milk } \\
\text { Production }\end{array}$ & $\begin{array}{l}10-15 \\
\text { littre/day/head of } \\
\text { milk cow }\end{array}$ & $\begin{array}{l}30-35 \\
\text { littre/day/head of } \\
\text { milk cow }\end{array}$ \\
\hline $\begin{array}{l}\text { Milk } \\
\text { distribution }\end{array}$ & $\begin{array}{l}\text { Cooperative Teller- } \\
>\text { and or Cooling } \\
\text { Unit -> Milk } \\
\text { Treatment -> Milk } \\
\text { Processing Industry }\end{array}$ & $\begin{array}{l}\text { Cooling unit- }>\text { Milk } \\
\text { Processing Industry }\end{array}$ \\
\hline $\begin{array}{l}\text { Production } \\
\text { unit }\end{array}$ & $\begin{array}{l}\text { Nuclear family of } \\
\text { dairy farmer }\end{array}$ & Employee, labor \\
\hline
\end{tabular}

To analyze the condition of dairy farmer community in Pangalengan, Bandung Regency, West Java Province that incorporated as active members in KPBS amidst the emergence of dairy farming enterprise who possesses greater capital, wide range of access and latest technological know-how, the researchers used dialectics approach from Marxist Perspective. As previously shown in Table 2, it can be seen that there were some discrepancies over production relations of dairy farmer community and dairy farmer enterprise in the pattern of production relations consisting of social confine, structure, nature of production relations, and marketing relations pattern. First, in dairy farmer communities, social confine was there was no external labor, except for those whose milking cow more than 10 , made them hire another person to help-either from extended family or from neighborhood or anyone that can be trusted. While in the enterprise, social confine of production relations was handed over by another person. Second, structure of production relations for dairy farmer community was egalitarian among the members of nuclear family, but if they possess more than 10 milking cows, there would be hirarchical potential. In the enterprise, the structure was hierarchical, shown by job specialization. And they bring in expatriate to be top manager. Third, the nature of production, for dairy farmer community, it was non exploitative-there was no forcing of work, anyone was free to decide how much work they would do, but in the enterprise, the nature of production was exploitative, that can be seen from boss-employee differences. Fourth, for marketing relations pattern, dairy farmer community have direct relations with cooperative (KPBS) while for enterprise there was no intermediary, it means that they market their product directly to the milk processing industries.

\section{Conclusion}

There was disparity between dairy farmer community and dairy farming enterprise in Pangalengan. Dialectics were seen from respective mode of production comprising production forces and production relations aspects. This research excluded capital formation of each party. Perhaps it will be useful to expand the research by including the capital formation as one of the component in the future.

\section{References and Notes}

1. R. Peet, and E. Hartwick, Theory of Development: Contentions, Arguments, Alternatives (Guilford Press, New York, US 2009).

2. Ollman, B. Alienation: Marx's Conception of Man in Capitalist Society, (Cambridge University Press 1976).

3. M. Idris, "Harga Daging Sapi Pernah Rp 80.000,00/kg 11 Tahun Lalu", Detik Finance, retrieved from https://finance.detik.com on October 1, 2017.

4. Statistik peternakan dan kesehatan hewan Livestock and animal health statistic, 2017. Direktorat Jenderal Peternakan dan Kesehatan Hewan, Kemeterian Pertanian, retrieved from http://ditjenpkh.pertanian.go.id on October 1, 2017.

5. Riethmuller, P and D. Smith, "Strengths and Weaknesses of The Indonesian Dairy Industry", retrieved October 12, 2017. http://www.fao.org/docrep/004/Ab986e/Ab986e $\underline{05 . \mathrm{Htm}}$

6. A. Mauludin, et.al, Jurnal Sosiohumaniora, 19 (2017). 